TITLE:

\title{
Immediate effects of stance and swing phase training on gait in patients with stroke(Abstract_要旨 )
}

AUTHOR(S):

Aoki(Sakuma), Kaoru

\section{CITATION:}

Aoki(Sakuma), Kaoru. Immediate effects of stance and swing phase training on gait in patients with stroke. 京都大学, 2021, 博士(人間健康科学)

\section{ISSUE DATE:}

2021-07-26

URL:

https://doi.org/10.14989/doctor.r13430

\section{RIGHT:}

許諾条件により本文は2022-06-01に公開; This is a non-final version of an article published in final form in "International Journal of Rehabilitation Research."

(https://journals.Iww.com/intjrehabilres/Abstract/2021/06000/Immediate_effects_of_sta nce_and_swing_phase.9.aspx) 


\begin{tabular}{|l|l|c|c|}
\hline 京都大学 & 博士 (人間健康科学) & 氏 名 & \multicolumn{1}{|l}{ 青木（佐久間） 香 } \\
論文題目 & $\begin{array}{l}\text { Immediate effects of stance and swing phase training on gait in patients } \\
\text { with stroke }\end{array}$
\end{tabular}
(脳卒中後片麻痺者における歩行立脚期と遊脚期を想定した練習の即時効果)

(論文内容の要旨)

脳卒中を発症すると, 運動障害や感覚障害が生じ歩行能力が低下寸ることが 多い。歩行障害の改善には，継続して行える簡単な運動療法の開発が必要であ る。歩行速度が低下しているほど，麻痺側の蹴り出しや振り出しが障害されて いることから，歩行立脚期や遊脚期を想定した簡単な練習に着目した。しかし， それぞれの練習効果の違いや効果が得られや寸い脳卒中後片麻痺者(以下，片麻 痺者)の特徵については明らかになっていない。片麻瘏者の身体機能は様々であ るため，身体機能によって効果的な練習が異なると考えた。

そこで, 本研究の目的を片麻癘者における歩行立脚期と遊脚期を想定した簡 単な練習の即時効果と, 練習の効果が得られやすい片麻痺者の特徵について明 らかにすることとした。

地域在住の片麻痺者 16 名を対象とし, 立脚期の練習と遊脚期の練習を 1 か月 以上空けた別日に行った。練習の順序は無作為とした。

立脚期の練習では，身体重心の軌跡が倒立振り子となることで足圧中心移動 距離が増加し，麻痺側の䟣り出しが改善されることを目標とし，立脚中期を想 定した練習, 立脚初期を想定した練習, 立脚期全体を想定した練習, および直 線歩行練習を行った。遊脚期の練習では，代償が生じずに振り出しを行えるこ とで麻痺側の振り出しが改善されることを目標とし, 麻痺側股関節の屈曲練習, 遊脚初期を想定した練習，遊脚期全体を想定した練習，および直線歩行練習を 行った。

各練習の前後に, 光学式 3 次元動作分析装置と床反力計を用いて快適歩行動 作の測定を行い，歩行指標・運動学指標・運動力学指標について即時効果を調 べた。次に，対象者毎に歩行速度の即時効果が大きかった練習を調べ，対象者 2 群に分類し，身体機能(Fugl-Meyer Assessment 下肢運動機能，感覚，䯸 縮，両下肢筋力, Timed Up and Go)における 2 群の違いを調べた。

4 名が脱落し，12 名が両方の練習を実施できた。練習の持ち越し効果や時期 効果は認めなかった。麻痺側立脚期の足圧中心移動距離について, 立脚期の練 習を行った方が，遊脚期の練習よりも増加した。他の歩行指標・運動学指標 • 運動力学指標については差を認めなかった。

遊脚期よりも立脚期の練習を行った方が歩行速度の向上が大きかった対象者は 6 名，立脚期よりも遊脚期の練習の方が大きかった対象者は 6 名であった。立脚 期の練習を行った方が歩行速度の向上が大きかった対象者は, 遊脚期の練習で大 きかった対象者よりも麻痺側の股関節屈曲筋力と伸展筋力が小さく， Timed Up and Go が遅かった。他の身体機能については差を認めなかった。

麻疩側立脚期の足圧中心移動距離が短く，歩行速度が遅い対象者について，立 脚期の練習を行うことで足圧中心移動距離を増加できたと考えられた。歩行速度 には練習効果の差を認めなかったことから，対象者の特徵によって有効な練習が 異なる可能性が考えられた。また, 股関節伸展筋が初期接地後における身体重心
の移動に重要であることから，股関節伸展筋力が小さい対象者では立脚期が障害 されている可能性が高く, 遊脚期の練習より立脚期の練習を行う方が歩行速度向 上に有効であったと考えられる。

本学位申請論文の結果より，麻痺側の股関節屈曲筋力と伸展筋力が小さく, Timed Up and Go が遅い片麻痺者には立脚期の練習，麻瘏側の股関節屈曲筋力と 伸展筋力が大きく, Timed Up and Go が速い片麻痺者には遊脚期の練習を行った 方が歩行速度向上に効果的である可能性が示された。

\section{(論文審査の結果の要旨)}

脳卒中後片麻痺者（片麻痺者）における歩行障害の改善と維持のためには、歩 行練習を継続して行う必要があることから、簡単に行える歩行練習が必要である。 また、片麻疩者の身体機能は様々であるため、練習に適した対象者の特徵を示す ことが求められるが、示された研究はほとんどない。そこで、本研究は片麻痺者 の歩行障害の原因と考えられる麻痺側蹴り出しの改善を目的とした簡単な立脚期 の練習と、麻痺側振り出しの改善を目的とした遊脚期の練習の即時効果の違い、 および練習効果が得られやすい対象者の特徴を明らかにすることを目的とした。 地域在住片麻痻者 16 名を対象とし、立脚期の練習と遊脚期の練習を 1 か月以上空 けた別日に行わせ、各練習の前後に 3 次元歩行動作解析装置と床反力を用いて歩 行動作を測定し、即時効果を調べた。さらに、歩行速度の即時効果が大きかった 練習によって対象者を 2 群に分類し、身体機能における 2 群の違いを調べた。そ の結果、麻瘏側の股関節筋力が小さく、Timed Up and Go が遅い対象者には立脚 期の練習、麻瘏側の股関節筋力が大きく、Timed Up and Go が速い対象者には遊 脚期の練習を行った方が歩行速度向上に効果的である可能性が示唆された。

以上の研究は脳卒中後片麻痺者が自宅で行える簡単な運動療法の解明に貢献 し、脳卒中後片麻痺者のリハビリテーションの発展に寄与するところが多い

したがって、本論文は博士（人間健康科学）の学位論文として価值あるものと認 める。

なお、本学位授与申請者は、令和 3 年 6 月 3 日実施の論文内容とそれに関連した 試問を受け、合格と認められたものである。 